\title{
Methods for Arylethylation of Amines and Heteroarenes
}

\author{
Franz Bracher* (D) \\ Department of Pharmacy - Center for Drug Research, Ludwig- \\ Maximilians University, Butenandtstr. 5-13, 81377 Munich, \\ Germany \\ Franz.Bracher@cup.uni-muenchen.de \\ Dedicated to my friend Norbert Breitschaft, who died on $7^{\text {th }}$ of \\ February, 2018.
}

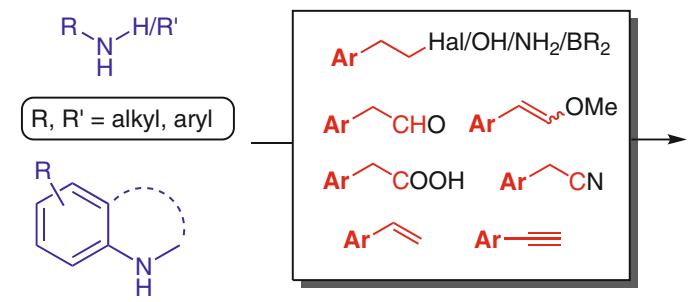<smiles>[R]c1ccccc1N1CCCCc2ccccc21</smiles>

Received: 21.02.2018

Accepted: 18.03.2018

Published online: 03.04 .2018

DOI: 10.1055/s-0037-1609449; Art ID: so-2018-d0020-r

License terms: cc)

Abstract Compared with standard $\mathrm{N}$-methylation, benzylation, and alkylation of amines and $\mathrm{N}$-heterocycles, $\mathrm{N}$-arylethylation is significantly more challenging. In this Review the available methods for $\mathrm{N}$-arylethylation are summarized, with a special focus on efficiency, selectivity, availability of the required building blocks, and ecological aspects.

Key words arylethylation, phenethylation, alkylation, reductive amination, hydroamination, reduction

\section{Introduction}

Amines are the one of the most important functional groups in low-molecular weight drugs. Due to their balanced basicity, an equilibrium between water-soluble protonated form and lipophilic, membrane-permeable neutral form exists, giving amines very favorable pharmacokinetic properties. Moreover, the protonated form strongly contributes to the interaction of the drug with the target proteins (enzymes, receptors, ion channels) because of their ability to build up ion-ion, ion-dipole, and $\pi$-cation interactions with amino acid residues in the active sites of the proteins. ${ }^{1}$

Consequently, a broad range of methods for the synthesis of amines is available, including convenient protocols for the introduction of methyl, alkyl, and benzyl residues. Surprisingly, only limited data are published on the introduction of phenethyl (and other arylethyl) residues, including examples of surprisingly unsuccessful attempts. ${ }^{2,3}$
The phenethyl residue has been found to be very advantageous in a number of drugs. In morphine-derived ${ }^{4}$ and related analgesics, ${ }^{5,6}$ as well as serotonin receptor ligands, ${ }^{7}$ this particular residue was essential for high pharmacological activities.

Furthermore, N-phenylethyl compounds are required for systematic analysis of structure-activity relationships in the development of novel amine-based drugs, if homologous series of compounds are investigated.

In the past decades, a number of novel methods for the introduction of $\mathrm{N}$-arylethyl residues have been developed, and these will be the subject of this review article.

The following items will be addressed in this review:

1. Which substrates (aliphatic amines, aromatic amines, $\mathrm{N}$-heteroarenes) can be subjected to this reaction, and how is the chemoselectivity?

2. Which functional groups are compatible with the reaction conditions and reagents?

3. How is the availability of the required building blocks and catalysts?

4. How about ecological aspects and atom economy?

\section{Methods for N-Arylethylation}

\subsection{N-Arylethylation with Phenethyl Halides and Sulfonates}

The most obvious method for converting amines into their $\mathrm{N}$-arylethyl analogues is $\mathrm{N}$-alkylation with appropriate arylethyl halides; in the most common case with commercially available phenethyl bromide. Depending on the nucleophilicity of the substrate, this conversion can be performed (in case of sufficient intrinsic nucleophilicity of the amine) by simply reacting the amine/heteroarene with the phenethyl halide in the presence of a weak base, which will 
neutralize the hydrogen halide formed in the course of the reaction. By this means, undesired protonation of substrate amine is avoided, ending up with (hopefully) full conversion of the starting amine. Commonly applied proton scavengers are carbonate salts such as $\mathrm{K}_{2} \mathrm{CO}_{3}, \mathrm{Na}_{2} \mathrm{CO}_{3}$, and $\mathrm{Cs}_{2} \mathrm{CO}_{3}$. Aliphatic (mostly secondary) amines, 5,8 and aniline derivatives $^{9-12}$ (including 1,2,3,4-tetrahydroquinoline ${ }^{8}$ and indolines ${ }^{13}$ ) are easily converted in this manner in moderate to good yields, as exemplified in Scheme 1. Primary aromatic amines give monoalkylated products in most cases.

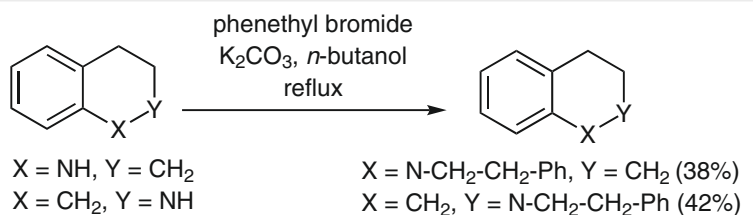

Scheme 1 Phenethylation of 1,2,3,4-tetrahydroisoquinoline and 1,2,3,4-tetrahydroquinoline ${ }^{8}$

In contrast, poorly nucleophilic substrates (e.g., indoles, ${ }^{14}$ carbazoles, ${ }^{15}$ carbolines, ${ }^{16}$ imidazoles, ${ }^{17}$ phenothiazines ${ }^{18}$ ) do not readily react with arylethyl halides, and notable conversions are obtained only if the $\mathrm{NH}$ groups of these substrates are deprotonated ahead, rendering the significantly more nucleophilic amide anions. The choice of the base is determined by the acidity of the $\mathrm{NH}$ function, and bases of moderate (alkali metal hydroxides, alkoxides, etc) to very strong basicity (butyllithium) have been used for this purpose. Undesired fragmentation of starting phenethyl halides ${ }^{19}$ and produced phenethylamines ${ }^{15}$ in the presence of very strong bases have been reported.

In general, phenethyl iodides show higher reactivity than the corresponding chlorides and bromides, ${ }^{9,12}$ and the reaction can be accelerated by in situ conversion of phenethyl bromide into phenethyl iodide by adding catalytic amounts of KI. ${ }^{12}$ However, there is also one report on undesired decomposition of phenethyl iodide under the reaction conditions. ${ }^{10}$ This reaction can further be speeded up by microwave irradiation (Scheme 2$).^{12}$

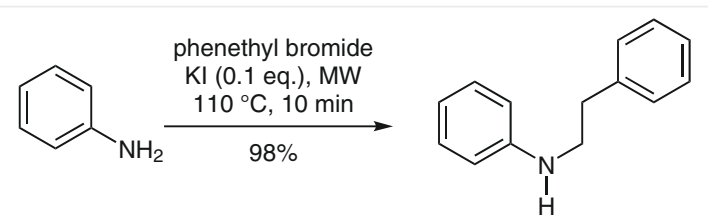

Scheme 2 Microwave- and iodide-accelerated phenethylation of aniline $^{12}$

Phenethyl mesylates ${ }^{20}$ and tosylates ${ }^{14}$ as well as polymer-bound arylethyl arenesulfonates ${ }^{21}$ can be applied as alternative phenethylating agents.

A phenethylation of an aniline with phenethyl bromide, catalyzed by a palladium complex (generated in situ from $\mathrm{Pd}_{2}(\mathrm{dba})_{3}$ and X-Phos) has been reported recently. ${ }^{22}$ The authors do not discuss why they utilized the Pd catalyst for this purpose.

For simple phenylethylation reactions, this direct N-alkylation is the method of choice in most cases. Unfortunately, only a very limited number of ring substituted arylethyl halides are commercially available, and synthesis of the required building blocks (mostly via the corresponding arylethanols) affords multistep procedures, starting from benzoic acids under homologation, ${ }^{20}$ styrenes via hydroboration/oxidation, ${ }^{23}$ or styrene oxides via reductive cleavage. $^{24}$

\subsection{N-Arylethylation with Arylethanols and Aryl- ethylamines}

As mentioned above, arylethanols are typical precursors of arylethyl halides and sulfonates as building blocks for $\mathrm{N}$ arylethylation. Alternatively, arylethanols can be activated directly for the envisaged conversions.

An N-phenethylation of phenothiazine using (4-bromophenyl)ethanol, activated in situ by propylphosphonic acid anhydride (T3P) gave only incomplete conversion (25\% yield), in contrast to high yields obtained with benzyl alcohols under the same conditions. ${ }^{25}$ Phenethylation of aniline using phenylethanol and $\mathrm{Ph}_{3} \mathrm{P} / \mathrm{DDQ}$ reagent in a Mitsuno-

\section{Biographical Sketches}

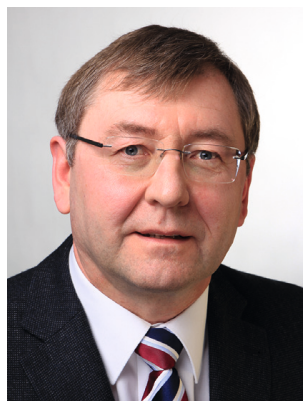

Franz Bracher was born in 1958 in Geisenfeld (Germany). He studied Pharmacy at the Ludwig-Maximilians University of Munich (LMU) and obtained his Dr. rer. nat. there in 1986 under the supervision of Eberhard Reimann. After one year as a postdoc with Prof. Dr. W. Oppol- zer at the University of Geneva (Switzerland) he moved to the Philipps University of Marburg (Germany), where he obtained his Habilitation in 1991. He was appointed an Associate Professor of Pharmaceutical Chemistry at the University of Braunschweig in 1992, since
1997 he is Full Professor of Pharmacy at LMU Munich. His research interests include natural products synthesis (especially alkaloids and steroids) and Medicinal Chemistry. He is an author of over 200 publications. 
Table 1 Metal-Catalyzed Arylethylation of Amines with Arylethanols

$\mathrm{RR} ' \mathrm{NH}+\mathrm{Ar}-\mathrm{CH}_{2}-\mathrm{CH}_{2}-\mathrm{OH} \longrightarrow \mathrm{RR}^{\prime} \mathrm{N}-\mathrm{CH}_{2}-\mathrm{CH}_{2}-\mathrm{Ar}$

\begin{tabular}{|c|c|c|c|c|}
\hline $\begin{array}{l}\text { Type of amines } \\
\text { (number of examples) }\end{array}$ & Arylethanol(s) & Catalyst & Yield (\%) & Ref. \\
\hline aniline (1) & phenylethanol & {$\left[\mathrm{Cp} * \operatorname{Ir}\left(\mathrm{NH}_{3}\right)_{3}\right][1]_{2}$} & 94 & 27 \\
\hline 4-methoxyaniline (1) & phenylethanol & Raney nickel & 78 & 28 \\
\hline $\begin{array}{l}\text { 2-aminopyridine, 1-phenylethylamine, aniline } \\
\text { (3) }\end{array}$ & $\begin{array}{l}\text { (substituted)phenylethanol, indole-3-etha- } \\
\text { nol }\end{array}$ & {$\left[\mathrm{Ru}(p \text {-cymene }) \mathrm{Cl}_{2}\right]_{2}$} & $70-93$ & 29 \\
\hline 4-methylaniline (1) & phenylethanol & $\mathrm{NiCuFeO}_{x}$ & 96 & 30 \\
\hline aniline (1) & phenylethanol & $\mathrm{Pt}-\mathrm{Sn} / \mathrm{Y}-\mathrm{Al}_{2} \mathrm{O}_{3}$ & 96 & 31 \\
\hline 4-methoxyaniline, morpholine (2) & phenylethanol & palladacycle, $\mathrm{P}(\text { furyl })_{3}$ & $72 / 74$ & 32 \\
\hline
\end{tabular}

bu related reaction was accomplished in 92\% yield, but the scope and limitations of this method have not been investigated. ${ }^{26}$

A considerable number of recent publications deal with the metal-catalyzed arylethylation of amines (mostly aniline derivatives) with arylethanols. These methods are summarized in Table 1.

In most cases, only single examples for phenethylation are presented, mainly in combination with $\mathrm{N}$-alkylations with other alcohols such as benzyl alcohols. The presented yields are impressive, but scope and limitations for arylethylations have not been investigated in these contributions.

In a similar manner, arylethylamines have been investigated as building blocks for metal-catalyzed arylethylations of amines. Catalyzed by a cobalt-pincer complex, aniline was phenylethylated with phenylethylamine to give $\mathrm{N}$ phenethylaniline in $64 \%$ yield, accompanied by $19 \%$ of the homocoupling product of phenylethylamine. ${ }^{33}$ In an intramolecular version of this reaction, indoline was obtained in $52 \%$ yield from 2-(2-aminoethyl)aniline (Scheme 3$){ }^{33}$

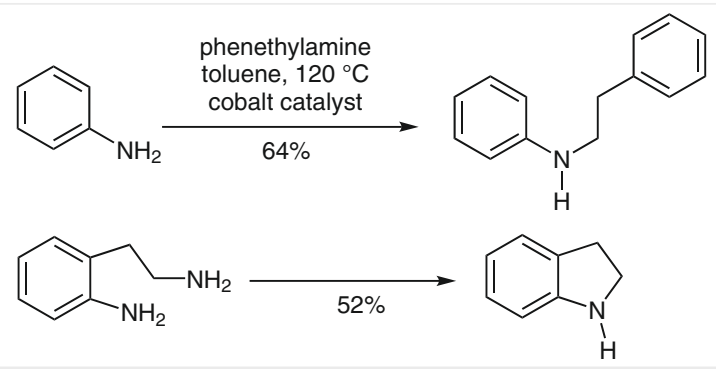

Scheme 3 Cobalt-catalyzed inter- and intramolecular phenylethylation reactions ${ }^{33}$

Aniline was N-alkylated with phenyl-, indole-, and thiophene-based primary arylethylamines to give the corresponding secondary amines under catalysis of a ruthenium carbonyl-phosphine complex ('Shvo-complex') in yields above $90 \%$ (three examples). ${ }^{34}$ Recently it was shown that phenethylation of aniline can even be catalyzed by reusable palladium on carbon catalyst, but the yield obtained with phenylethylamine (36\%) was considerably lower than yields obtained with other primary aliphatic amines (72-94\%). ${ }^{35}$

\section{$2.3 \quad$ N-Arylethylation with Phenethyl Boron Compounds}

An additional building block of the type 'arene- $\mathrm{CH}_{2}$ $\mathrm{CH}_{2}$-heteroatom' are phenethyl boron compounds, which were introduced only recently. Promoted by $\mathrm{Cu}(\mathrm{OAc})_{2}$ and pyridine (4 equiv each), ring-substituted anilines undergo convenient $\mathrm{N}$-phenethylation with phenethylboronic acid (yields 63-94\%). This protocol was also applied to aminopyridines and aminoquinolines, and variable yields (0-80\%) were obtained (Scheme 4). ${ }^{19}$ This methodology can also be applied to the $\mathrm{N}$-arylethylation of benzamides. ${ }^{36,37}$ Phenethylboronic acids are available from styrenes via hydroboration with dichloroborane, followed by aqueous hydrolysis. ${ }^{38}$

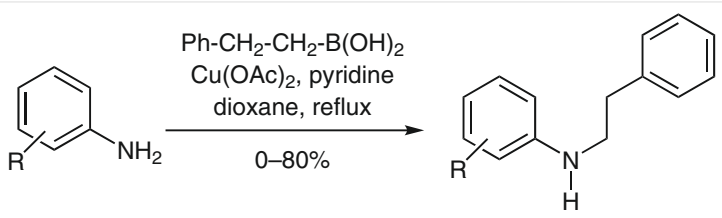

Scheme 4 Copper-promoted phenethylation of anilines with phenethylboronic acid ${ }^{19}$

In 2012, this methodology was extended to phenethylboranes. ${ }^{39}$ These can conveniently be prepared in situ from styrenes via hydroboration. Two different approaches were investigated: A mixed trialkylborane obtained by hydroboration of a styrene with 9-BBN, under $\mathrm{Cu}(\mathrm{OAc})_{2}$-pyridine promotion, unfortunately showed very poor conversion with an aniline. Significantly better yields were obtained with tri(arylethyl)boranes obtained by hydroboration of styrenes with $\mathrm{BH}_{3}$-THF complex. A broad variety of ringsubstituted styrenes and anilines were subjected to this 
reaction, and yields in the range of $26-76 \%$ were obtained. Unfortunately, equimolar amounts of the boranes (resulting from borane and three equivalents of styrene) were required, meaning that this method is not atom-economic (Scheme 5).

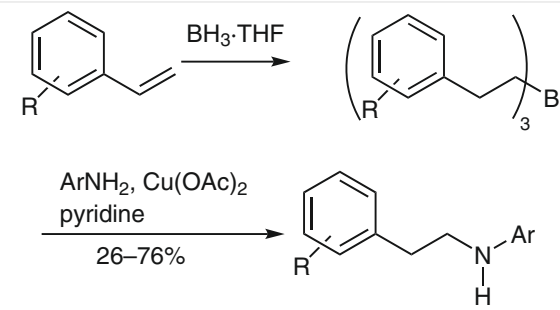

Scheme 5 Copper-promoted phenethylation of anilines with tri(arylethyl)boranes ${ }^{39}$

In analogy, phenethylbismuth compounds can be used for copper-promoted phenethylation of aromatic and aliphatic amines, but yields were rather poor (up to 53\%) due to the tendency of the organobismuth compounds to undergo $\beta$-elimination (giving styrene) under the reaction conditions. ${ }^{40}$

\subsection{N-Arylethylation via Arylacetamides}

A classical method for obtaining arylethylamines consists of N-acylation of primary or secondary amines with activated arylacetic acids, followed by reduction of the formed amide moiety to the corresponding amine (Scheme 6). Numerous methods for amide reductions have been published, and it is beyond the scope of this mini-review to present a comprehensive list of methods. The most prominent reducing agents are $\mathrm{LiAlH}_{4}, \mathrm{NaBH}_{4}$ (with different additives such as $\mathrm{BF}_{3}$ and acetic acid), and diborane and borane complexes. Furthermore, silanes in combination with reagents such as titanocene difluoride, ${ }^{41}$ rhodium-phosphine complexes, ${ }^{42}$ or 2-fluoropyridine/trifluoromethanesulfonic anhydride ${ }^{43}$ have been applied. The choice of the reducing agent is dictated by the presence of other functional groups in the amide and the required chemoselectivity.

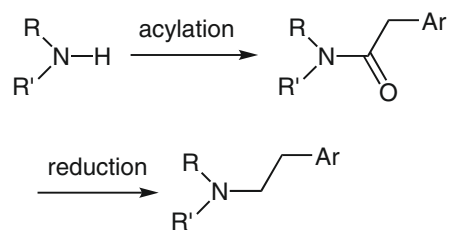

Scheme 6 Preparation of arylethylamines via reduction of arylacetamides
One major advantage of this protocol is that primary amines can be converted into secondary $\mathrm{N}$-phenethylamines without over-alkylation. This protocol is of limited applicability for the N-phenethylation of indoles and related heterocycles because $\mathrm{N}$-acyl derivatives thereof readily undergo reductive deacylation with reducing agents. ${ }^{44}$

Arylacetic acids with complex substitution patterns often need to be prepared from common aromatic building blocks in multistep syntheses. ${ }^{45}$

In a related approach, aromatic amines were arylethylated in high yields in one step by treatment with (substituted) arylacetic acids under catalytic hydrogenation (60 bar $\mathrm{H}_{2}, 160{ }^{\circ} \mathrm{C}$ ) in the presence of catalytic amounts of $\mathrm{Ru}(\mathrm{acac})_{3}$, Triphos, and triflimide (Scheme 7). ${ }^{46}$ Aniline has been converted into its $\mathrm{N}$-phenethyl derivative with methyl phenylacetate by following the same procedure; furthermore, numerous other aliphatic and aromatic amines have been $\mathrm{N}$-alkylated with other methyl esters. ${ }^{47}$ A related phenethylation of aniline with phenylacetic acid has been performed under Pt-catalysis (Karstedt's catalyst) using $\mathrm{PhSiH}_{3}$ as the reductant. ${ }^{48}$

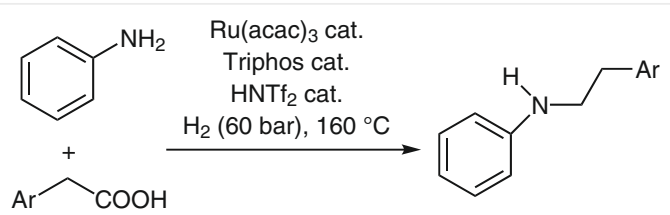

Scheme 7 Reductive N-arylethylation of aromatic amines with arylacetic acids ${ }^{46}$

\subsection{Reductive Amination of Arylacetaldehydes and Equivalents}

Reductive aminations of aldehydes and ketones with primary or secondary amines in the presence of appropriate reducing agents are a highly appreciated methodology for the synthesis of secondary and tertiary amines. These protocols are user-friendly because they do not require hazardous alkyl halides, and due to the mild conditions, undesired formation of quaternary ammonium salts (a common side reaction in standard $\mathrm{N}$-alkylation reactions) does not take place. Consequently, this methodology has found broad application in organic synthesis. Furthermore, most of these methods can be performed under metal-free conditions, which makes them ecologically advantageous.

Only a limited number of examples are known for reductive phenethylations of amines with phenylacetaldehyde. This is due to the high susceptibility of phenylacetaldehyde to undergo decomposition and polymerization; Table 2 gives an overview on the published conversions. 
Table 2 Reductive N-Phenethylations of Amines using Phenylacetaldehyde

$\mathrm{RR} ' \mathrm{NH}+\mathrm{Ph}-\mathrm{CH}_{2}-\mathrm{CHO} \longrightarrow \mathrm{RR}^{\prime} \mathrm{N}-\mathrm{CH}_{2}-\mathrm{CH}_{2}-\mathrm{Ph}$

\begin{tabular}{|c|c|c|c|c|}
\hline $\begin{array}{l}\text { Type of amines } \\
\text { (number of examples) }\end{array}$ & Reducing agent & Comments & Yield (\%) & Ref. \\
\hline 1,2,3,4-tetrahydro-quinoline (1) & $\mathrm{NaCNBH}_{3}$ & & 27 & 49 \\
\hline highly substituted anilines (2) & $\mathrm{NaBH}(\mathrm{OAC})_{3}$ & & 41,56 & 50 \\
\hline highly substituted indolines (3) & $\mathrm{NaBH}(\mathrm{OAC})_{3}, \mathrm{AcOH}$ & & $57-70$ & 13 \\
\hline 4-aminobenzoic acid & $\mathrm{BH}_{3}$-picoline & exact yield not given & $70-90$ & 51 \\
\hline aniline, isopropylamine (3) & $\mathrm{Bu}_{2} \mathrm{SnClH}$ & highly toxic solvent HMPA & $33-99$ & 52,53 \\
\hline 4-methylaniline (1) & $\mathrm{PhMe}_{2} \mathrm{SiH}$ & gold-carbon nanotube catalyst & 81 & 54 \\
\hline $\begin{array}{l}\text { aniline, } \\
\text { benzylamine (2) }\end{array}$ & $\begin{array}{l}\mathrm{HCOOH}-\mathrm{Et}_{3} \mathrm{~N} \\
\mathrm{Ru}(\mathrm{II}) \text { complex }\end{array}$ & Noyori's catalyst & $\begin{array}{l}62 \\
61\end{array}$ & 55 \\
\hline highly substituted indolines (2) & $\mathrm{H}_{2}$ (1 atm), $\mathrm{PtO}_{2}$ & & $41-62$ & 13 \\
\hline aniline (1) & $\begin{array}{l}\mathrm{Et}_{3} \mathrm{SiH}, \mathrm{TFA} \text {, } \\
\text { cat. } \mathrm{I}_{2}\end{array}$ & phenylacetaldehyde dimethyl acetal used & 85 & 56 \\
\hline
\end{tabular}

Besides common reducing agents $\left(\mathrm{NaCNBH}_{3}\right.$, $\left.\mathrm{NaBH}(\mathrm{OAc})_{3}, \mathrm{H}_{2} / \mathrm{Pt}\right)$, tin hydrides and organosilanes were successfully applied. Problems with the unstable phenylacetaldehyde were overcome by using the corresponding dimethyl acetal, in combination with a silane reducing agent. ${ }^{56} \mathrm{~A}$ convenient enhancement was achieved by using methoxystyrenes as phenylacetaldehyde equivalents. ${ }^{57}$ These building blocks are more stable than the parent aldehydes and are easily prepared in one step from commercially available (hetero)aromatic aldehydes by Wittig homologation (Scheme 8). In combination with triethylsilane and TFA, N-arylethylations of moderately basic amines (anilines, diphenylamine, 1,2,3,4-tetrahydroquinoline) and heterocycles (indoles, carbazoles, phenothiazine, dibenzazepines) were achieved in yields up to $94 \%$ ( 17 examples). Due to the strongly acidic reaction conditions (TFA) aliphatic amines are not affected because they are protected from electrophilic attack by protonation. The so obtained chemoselectivity is complementary to the chemoselectivity in reductive $\mathrm{N}$-arylethylation of amines using borohydride-type reducing agents.

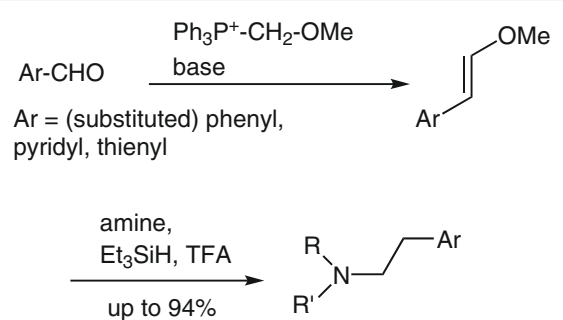

amine = aniline derivative, diphenylamine, indole, carbazole, phenothiazine, ...

Scheme 8 Reductive N-arylethylation of aromatic amines and N-heterocycles using methoxystyrenes ${ }^{57}$
Alternatively, anilines can be phenethylated through the use of styrene oxides, with a $\mathrm{B}\left(\mathrm{C}_{6} \mathrm{~F}_{5}\right)_{3}$-catalyzed Meinwald rearrangement giving intermediate arylacetaldehydes as the initial step. Crude aldehyde is condensed with an aniline and the formed imine is reduced with an organosilane to give the target products. High yields of $\beta, \beta$-diarylamines are obtained, whereas the parent phenethyl residue is introduced only in poor yield (Scheme 9$){ }^{58}$

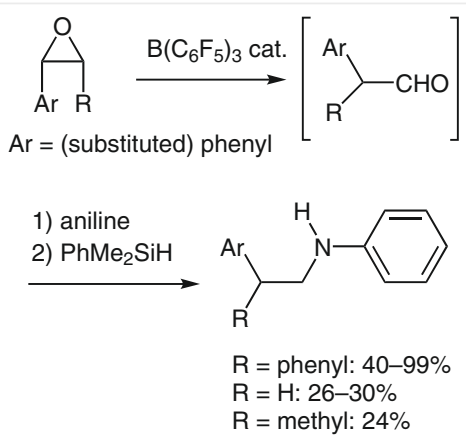

Scheme 9 Reductive $\mathrm{N}$-arylethylation of aromatic amines with styrene oxides utilizing a Meinwald rearrangement ${ }^{58}$

As a further surrogate of arylacetaldehydes, arylacetonitriles are applicable. The latter are easily available from the corresponding benzyl halides. This approach consists of an in situ reduction of the nitrile group to an aldimine, followed by condensation with a primary or secondary amine (releasing $\mathrm{NH}_{3}$ ), and a second reduction step to give the target compounds. Representative examples are shown in Table 3 . 
Table 3 Reductive N-Phenethylations of Amines using Arylacetonitriles

$\mathrm{RR}{ }^{\prime} \mathrm{NH}+\mathrm{Ph}-\mathrm{CH}_{2}-\mathrm{CN} \longrightarrow \mathrm{RR}^{\prime} \mathrm{N}-\mathrm{CH}_{2}-\mathrm{CH}_{2}-\mathrm{Ph}$

\begin{tabular}{|c|c|c|c|c|}
\hline $\begin{array}{l}\text { Type of amines } \\
\text { (number of examples) }\end{array}$ & Reducing agent & Comments & Yield (\%) & Ref. \\
\hline $\begin{array}{l}\text { aniline, } \\
n \text {-pentylamine (2) }\end{array}$ & $\begin{array}{l}\mathrm{BH}_{3}-\mathrm{NH}_{3}, \\
\mathrm{Co}(\mathrm{III} \text {-pincer-catalyst }\end{array}$ & numerous examples with other nitriles & $\begin{array}{l}69 \\
68\end{array}$ & 59 \\
\hline aniline (1) & $\mathrm{H}_{2}, \mathrm{Pd} / \mathrm{C}$ & numerous examples with alkanenitriles & not given & 60 \\
\hline $\begin{array}{l}\mathrm{Me}_{2} \mathrm{NH}, \mathrm{Et}_{2} \mathrm{NH} \text {, piperidine, benzylamine } \\
\text { (4) }\end{array}$ & $\mathrm{H}_{2}, \mathrm{Pd} / \mathrm{C}$ & methoxy- and hydroxyphenylacetonitriles used & $>70$ & 61 \\
\hline $\begin{array}{l}\text { aniline or nitrobenzene (as precursor of } \\
\text { aniline) (2) }\end{array}$ & $\mathrm{H}_{2}, \mathrm{Pd} / \mathrm{C}$ & $\begin{array}{l}5 \text { equiv of nitrile used; numerous examples with } \\
\text { other nitriles }\end{array}$ & $24\left(100^{\mathrm{a}}\right)$ & 62 \\
\hline
\end{tabular}

${ }^{a}$ If starting from nitrobenzene.

The target products can be contaminated with a number of byproducts: ${ }^{59,62}$ Hereby, the starting arylacetonitriles are reduced to the primary arylethylamines, which, in turn, can condense with the intermediate aldimines to give, after further reduction, symmetrical di(arylethyl)amines. The outcome of the reaction strongly depends on the exact reaction conditions and on the nature of the substrate amines and arylacetontiriles.

\subsection{N-Arylethylation via Addition of Amines to Sty- renes}

The direct, regioselective anti-Markovnikov-type $\beta$-addition of amines to vinylarenes (styrenes) is an approach of highest atom economy for the synthesis of $\mathrm{N}$-arylethylated amines. Much work has been published on metal catalysts for promoting this addition (rare earth metals such as Ln complexes, $\mathrm{TiCl}_{4}$, Rh complexes, etc), but frequently these additions are hampered by poor or unpredictable regioselectivity. Details have been summarized in a number of comprehensive review articles. ${ }^{63-65}$ The outcome of the addition is further dependent on the substitution pattern of the vinylarene, as exemplified in the Cu-carbene-catalyzed additions of aliphatic and aromatic amines to styrenes (Scheme 10). ${ }^{66}$

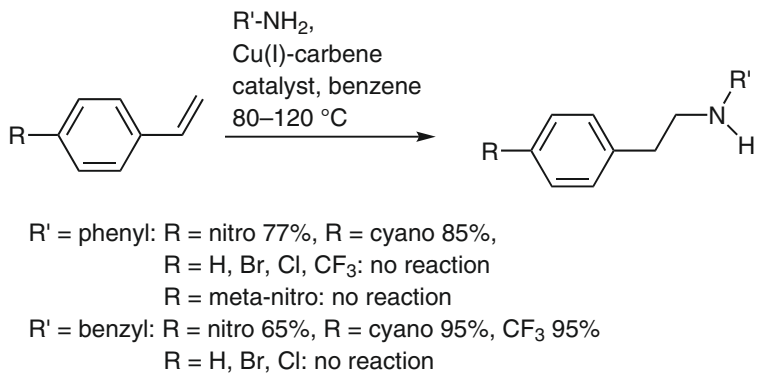

Scheme 10 Cu-carbene-catalyzed additions of aniline and benzylamine to substituted styrenes ${ }^{66}$
In practice, this addition to unactivated styrenes is most likely triggered by stoichiometric or catalytic amounts of bases, which convert the amine into a more nucleophilic amide ion. Styrenes bearing electron-withdrawing substituents can undergo this reaction even without support of a base. ${ }^{64} \mathrm{~A}$ broad range of bases have been applied (BuLi, ${ }^{67,68}$ $\mathrm{KOtBu},{ }^{69,70}$ lithium dialkylamides, ${ }^{71,72} \mathrm{NaH},{ }^{68} \mathrm{KOH},{ }^{73} \mathrm{CsOH} ;{ }^{74}$ for further examples see ref.63). In additions of vinylpyridines and styrene to an annulated indole, significant differences in reactivity were observed, as pointed out in Scheme $11 .^{7,75}$ Satisfactory conversion was obtained with 4- and 2vinylpyridine, which are known to be highly reactive Michael systems, whereas 3-vinylpyridine requires harsher reaction conditions, and styrene gave no conversion at all.

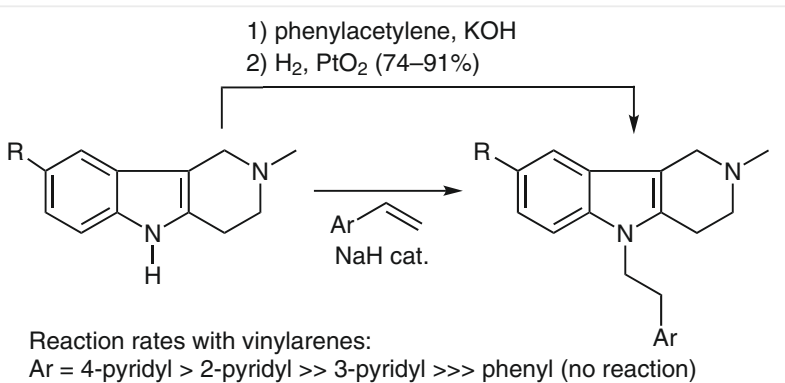

Scheme 11 Reactivities of vinylarenes in $\mathrm{NaH}$-catalyzed additions to indoles. Alternative phenethylation via hydroamination of phenylacetylene, followed by catalytic hydrogenation of the resulting enamine (see Section 2.7). ${ }^{75}$

\subsection{N-Arylethylation via Hydroamination/Reduc- tion of Arylacetylenes}

Addition of amines to arylacetylenes can be catalyzed by a large number of metal catalysts, whereby mostly mixtures of enamines consisting of the desired anti-Markovnikov products as well as Markovnikov products, are obtained. The chemistry of this step (hydroamination) has been summarized in a number of comprehensive review articles. ${ }^{63,64,76}$ Late-transition-metal catalysts give mostly or exclusively Markovnikov addition products with terminal 
alkynes, whereas some titanium catalysts lead to the desired anti-Markovnikov addition. ${ }^{77,78}$ Typically, these intermediates are reduced in situ to give the corresponding isomeric arylethylamines (Scheme 12). The reduction can be accomplished by catalytic hydrogenation over Pt catalyst ${ }^{7}$ (see Scheme 11), or with $\mathrm{LiAlH}_{4}{ }^{77}$ and organosilanes such as $\mathrm{PhSiH}_{3}{ }^{78}$ Nevertheless, the regioselectivity of the hydroamination is strongly dependent on the substitution patterns of the reactands, and even small changes can result in a significant loss in regioselectivity. ${ }^{78}$

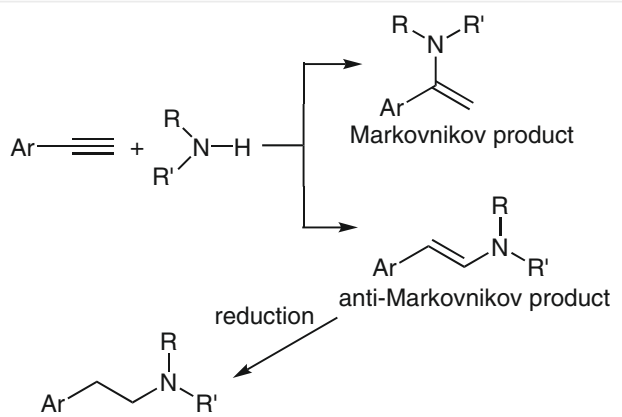

Scheme 12 Hydroamination of arylacetylenes, followed by reduction to give $\mathrm{N}$-arylethyl products

Excellent regioselectivities and yields were obtained with a bis(amidate)bis(amido)titanium(IV) complex for the hydroamination of aliphatic amines as well as anilines bearing either electron-donating or electron-withdrawing substituents. ${ }^{77}$ However, substituents on the anilines (cyano, chloro), which were sensitive to the conditions of catalytic hydrogenation in the second step, led to complete failure of the arylethylation reaction (Scheme 13).

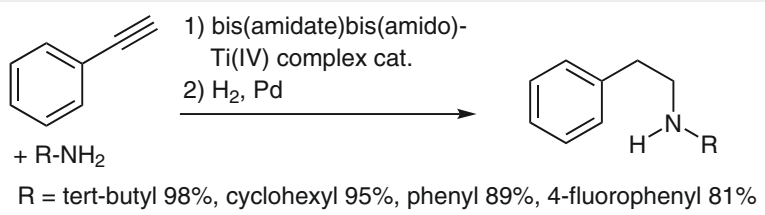

Scheme 13 Titanium-catalyzed hydroamination/reduction of arylacetylenes with amines ${ }^{77}$

\subsection{Sequential Construction of the Arylethyl Moi- ety}

A formal arylethylation of amines can further be accomplished in two steps, involving attaching an appropriate $C_{1}$ unit to the amine, followed by $\mathrm{C}, \mathrm{C}$-connection with a benzyl-type building block. In these protocols, a secondary (and in some examples a primary) amine is reacted with a reactive $C_{1}$-building block to give a (precursor of) an iminium ion, to which then an organometallic benzyl unit is added. A first example was published by Katritzky in 1998, involving condensation of benzotriazole with formaldehyde and amines to give $\mathrm{N}$-(aminomethyl)benzotriazoles, which react with benzylzinc compounds to give the arylethylated amines (Scheme 14, A). ${ }^{79}$ A similar conversion was obtained with benzylbismuth compounds prepared in situ. ${ }^{80}$

In a related approach, Knochel converted secondary aliphatic and aromatic amines, as well as N-heterocycles (phenoxazine, phenothiazine, carbazole) with Tietze's iminium salt $\left(\mathrm{Me}_{2} \mathrm{NCH}_{2}{ }^{+} \mathrm{CF}_{3} \mathrm{COO}^{-}\right)$, generated in situ, into mixed aminals, which, after activation with trifluoroacetic anhydride (TFAA), gave iminium salts that readily reacted with benzylic zinc compounds to give the $\mathrm{N}$-arylethylated amines in a one-pot-procedure (Scheme 14, B). ${ }^{81}$

A:

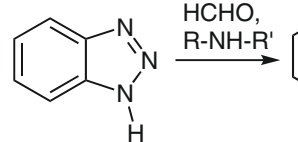<smiles>PNCn1nnc2ccccc21</smiles>

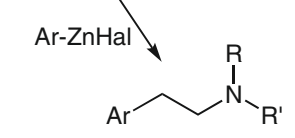

B: 1) TFAA 2) $\mathrm{Ar}-\mathrm{ZnC}$<smiles></smiles>

Scheme $14 \mathrm{~N}$-Arylethylation of amines under sequential construction of the arylethyl moiety. (A) Katritzky's method employing benzotriazoles. ${ }^{79}$ (B) Knochel's one-pot method. ${ }^{81}$

A two-step N-phenethylation of carbazoles involves $\mathrm{N}$ phenylthiomethylation, followed by deprotonation of the slightly acidic methylene group with $n$-butyllithium, and Cbenzylation with a benzyl halide. Reductive desulfurization of the intermediate phenylthio compound gave the desired $\mathrm{N}$-phenethylcarbazole (Scheme 15). ${ }^{82}$

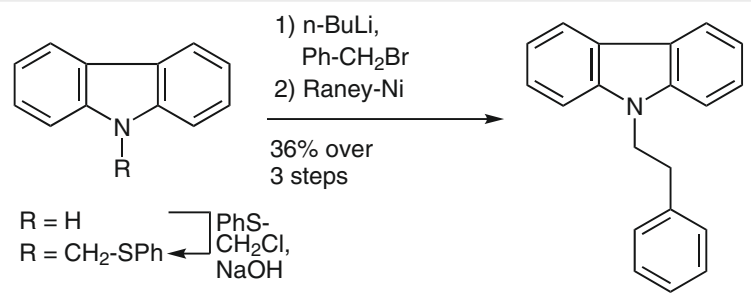

Scheme 15 N-Arylethylation of carbazole via a N-(phenylthio)methyl intermediate ${ }^{82}$

\section{Conclusion}

Compared with standard N-methylation, benzylation, and alkylation of amines and $\mathrm{N}$-heterocycles, $\mathrm{N}$-arylethylation is significantly more challenging. In this Review, the available methods for $\mathrm{N}$-arylethylation are summarized, with a special focus on efficiency, selectivity, availability of 
the required building blocks, and ecological aspects. Depending on the nature of substrate amine and (hetero)arylethyl residue to be introduced, a broad variety of (in part complementary) methodologies is available now. Chemoselectivity can be achieved by proper choice of the methodology, and high yields can be obtained by utilizing modern variations of established methods.

\section{References}

(1) Manallack, D. T.; Prankerd, R. J.; Yuriev, E.; Oprea, T. I.; Chalmers, D. K. Chem. Soc. Rev. 2013, 42, 485.

(2) Dong, H.; Latka, R. T.; Driver, T. G. Org. Lett. 2011, 13, 2726.

(3) Wekesa, F. S.; Phadke, N.; Jahier, C.; Cordes, D. B.; Findlater, M. Synthesis 2014, 46, 1046.

(4) Ben Haddou, T.; Béni, S.; Hosztafi, S.; Malfacini, D.; Calo, G.; Schmidhammer, H.; Spetea, M. PLoS ONE 2014, e99231.

(5) Lim, H. J.; Dersch, C. M.; Rothman, R. B.; Deschamps, J. R.; Jacobson, A. E.; Rice, K. C. Eur. J. Med. Chem. 2013, 67, 335.

(6) Hutchison, A. J.; de Jesus, R.; Williams, M.; Simke, J. P.; Neale, R. F.; Jackson, R. H.; Ambrose, F.; Barbaz, B. J.; Sills, M. A. J. Med. Chem. 1989, 32, 2221.

(7) Ivachtchenko, A. V.; Frolov, E. B.; Mitkin, O. D.; Tkachenko, S. E.; Okun, I. M.; Khvat, A. V. Bioorg. Med. Chem. Lett. 2010, 20, 78.

(8) Mokrosz, J. L.; Bojarski, A. J.; Charakchieva-Minol, S.; Duszynska, B.; Mokrosz, M. J.; Paluchowska, M. H. Arch. Pharm. (Weinheim) 1995, 328, 604.

(9) Birnbaum, L. S.; Powell, G. J. Am. Chem. Soc. 1945, 67, 1464.

(10) Forrest, J.; Liddell, D. A.; Tucker, S. H. J. Chem. Soc. 1946, 454.

(11) Albright, J. D.; DeVries, V. G.; Largis, E. E.; Miner, T. G.; Reich, M. F.; Schaffer, S. A.; Shepherd, R. G.; Upeslacis, J. J. Med. Chem. 1983, 26, 1378.

(12) Romera, J. L.; Cid, J. M.; Trabanco, A. A. Tetrahedron Lett. 2004, $45,8797$.

(13) Sato, K.; Takahagi, H.; Yoshikawa, T.; Morimoto, S.; Takai, T.; Hidaka, K.; Kamaura, M.; Kubo, O.; Adachi, R.; Ishii, T.; Maki, T.; Mochida, T.; Takekawa, S.; Nakakariya, M.; Amano, N.; Kitazaki, T. J. Med. Chem. 2015, 58, 3892.

(14) Tsotinis, A.; Vlachou, M.; Eleutheriades, A.; Prinea, E.; Ebreo, D.; The, M.-T.; Sugden, D. Chem. Pharm. Bull. 2002, 50, 31.

(15) Eisch, J. J.; Dua, S. K.; Kovacs, C. A. J. Org. Chem. 1987, 52, 4437.

(16) Otto, R.; Penzis, R.; Gaube, F.; Winckler, T.; Appenroth, D.; Fleck, C.; Tränkle, C.; Lehmann, J.; Enzensperger, C. Eur. J. Med. Chem. 2014, 87, 63.

(17) Rupčić, R.; Modrić, M.; Hutinec, A.; Čikoš, A.; Stanić, B.; Mesić, M.; Pešić, D.; Merćep, M. J. Heterocycl. Chem. 2010, 47, 640.

(18) Clarke, D.; Gilbert, B. C.; Hanson, P.; Kirk, C. M. J. Chem. Soc., Perkin Trans. 2 1978, 1103.

(19) Larrosa, M.; Guerrero, C.; Rodríguez, R.; Cruces, J. Synlett 2010, 2101.

(20) Black, L. A.; Nersesian, D. L.; Sharma, P.; Ku, Y.-Y.; Bennani, Y. L.; Marsh, K. C.; Miller, T. R.; Esbenshade, T. A.; Hancock, A. A.; Cowart, M. Bioorg. Med. Chem. Lett. 2007, 17, 1443.

(21) Rueter, J. K.; Nortey, S. O.; Baxter, E. W.; Leo, G. C.; Reitz, A. B. Tetrahedron Lett. 1998, 39, 975.

(22) Zhao, L.; Cao, D.; Chen, T.; Wang, Y.; Miao, Z.; Xu, Y.; Chen, W.; Wang, X.; Li, Y.; Du, Z.; Xiong, B.; Li, J.; Xu, C.; Zhang, N.; He, J.; Shen, J. J. Med. Chem. 2013, 56, 3833.

(23) Li, A.; Mishra, Y.; Malik, M.; Wang, Q.; Li, S.; Taylor, M.; Reichert, D. E.; Luedtke, R. R.; Mach, R. H. Bioorg. Med. Chem. 2013, 21, 2988.
(24) Yakabe, S. Synth. Commun. 2010, 40, 1339.

(25) Levi, L.; Scheuren, S.; Müller, T. J. J. Synthesis 2014, 46, 3059.

(26) Iranpoor, N.; Firouzabadi, H.; Nowrouzi, N.; Khalili, D. Tetrahedron 2009, 65, 3893.

(27) Kawahara, R.; Fujita, K.-i.; Yamaguchi, R. Adv. Synth. Catal. 2011, $353,1161$.

(28) Mehta, A.; Thaker, A.; Londhe, V.; Nandan, S. R. Appl. Catal., A: General 2014, 478, 241.

(29) Hamid, M. H. S. A.; Williams, J. M. J. Chem. Commun. 2007, 725.

(30) Cui, X.; Dai, X.; Deng, Y.; Shi, F. Chem. Eur. J. 2013, 19, 3665.

(31) Wu, K.; He, W.; Sun, C.; Yu, Z. Tetrahedron 2016, 72, 8516.

(32) Mamidala, R.; Mukundam, V.; Dhanunjayarao, K.; Venkatasubbaiah, K. Tetrahedron 2017, 73, 2225.

(33) Yin, Z.; Zeng, H.; Wu, J.; Zheng, S.; Zhang, G. ACS Catal. 2016, 6, 6546.

(34) Hollmann, D.; Bähn, S.; Tillack, A.; Beller, M. Angew. Chem. Int. Ed. 2007, 46, 8291.

(35) Linciano, P.; Pizzetti, M.; Porcheddu, A.; Taddei, M. Synlett 2013, 24, 2249.

(36) Mori-Quiroz, L. M.; Shimkin, K. W.; Rezazadeh, S.; Kozlowski, R. A.; Watson, D. A. Chem. Eur. J. 2016, 22, 15654.

(37) Rossi, S. A.; Shimkin, K. W.; Xu, Q.; Mori-Quiroz, L. M.; Watson, D. A. Org. Lett. 2013, 15, 2314.

(38) Josyula, K. V. B.; Gao, P.; Hewitt, C. Tetrahedron Lett. 2003, 44, 7789.

(39) Naya, L.; Larrosa, M.; Rodríguez, R.; Cruces, J. Tetrahedron Lett. 2012, 53, 769 .

(40) Barton, D. H. R.; Ozbalik, N.; Ramesh, M. Tetrahedron Lett. 1988, $29,857$.

(41) Selvakumar, K.; Rangareddy, K.; Harrod, J. F. Can. J. Chem. 2004, $82,1244$.

(42) Dittrich-Wengenroth, E.; Siegel, S.; Woltering, M. PCT Int. Appl. WO2005019169 A2, 2005.

(43) Pelletier, G.; Bechara, W. S.; Charette, A. B. J. Am. Chem. Soc. 2010, 132, 12817

(44) Neumann, W.; Frank, R.; Hey Hawkins, E. Dalton Trans. 2015, 1748.

(45) Song, B.; Rudolphi, F.; Himmler, T.; Gooßen, L. J. Adv. Synth. Catal. 2011, 353, 1565.

(46) Sorribes, I.; Cabrero-Antonino, J. R.; Vicent, C.; Junge, K.; Beller, M. J. Am. Chem. Soc. 2015, 137, 13580.

(47) Adam, R.; Cabrero-Antonino, J. R.; Junge, K.; Jackstell, R.; Beller, M. Angew. Chem. 2016, 128, 11215.

(48) Sorribes, I.; Junge, K.; Beller, M. J. Am. Chem. Soc. 2014, 136, 14314.

(49) Eggler, J. F.; Holland, G. F.; Johnson, M. R.; Volkmann, R. A. U. S. US 4738972A, 1988.

(50) Parlow, J. J.; Stevens, A. M.; Stegeman, R. A.; Stallings, W. C.; Kurumbail, R. G.; South, M. S. J. Med. Chem. 2003, 46, 4297.

(51) Long, K.; Edwards, T. A.; Wilson, A. J. Bioorg. Med. Chem. 2013. $21,4034$.

(52) Shibata, I.; Suwa, T.; Sugiyama, E.; Baba, A. Synlett 1998, 1081.

(53) Suwa, T.; Sugiyama, E.; Shibata, I.; Baba, A. Synthesis 2000, 789.

(54) Kumar, R.; Gravel, E.; Hagège, A.; Li, H.; Verma, D.; Namboothiri, I. N. N.; Doris, E. ChemCatChem 2013, 5, 3571.

(55) Zhu, M. Catal. Lett. 2014, 144, 1568.

(56) Zhang, X.-L.; Yu, P.; Wu, Y.-W.; Wu, Q.-P.; Zhang, Q.-S. J. Chem. Res. 2014, 38, 261.

(57) Vögerl, K.; Ong, D. N.; Bracher, F. Synthesis 2018, 50, 1323.

(58) Tiddens, M. R.; Klein Gebbink, R. J. M.; Otte, M. Org. Lett. 2016, $18,3714$.

(59) Shao, Z.; Fu, S.; Wei, M.; Zhou, S.; Liu, Q. Angew. Chem. Int. Ed. 2016, 55, 14653. 
(60) Sajiki, H.; Ikawa, T.; Hirota, K. Org. Lett. 2004, 6, 4977.

(61) Kindler, K.; Schrader, K.; Middelhoff, B. Arch. Pharm. 1950, 283, 184.

(62) Ikawa, T.; Fujita, Y.; Mizusaki, T.; Betsuin, S.; Takamatsu, H.; Maegawa, T.; Monguchi, Y.; Sajiki, H. Org. Biomol. Chem. 2012, 10, 293.

(63) Müller, T. E.; Beller, M. Chem. Rev. 1998, 98, 675.

(64) Müller, T. E.; Hultzsch, K. C.; Yus, M.; Foubelo, F.; Tada, M. Chem. Rev. 2008, 108, 3795.

(65) Huang, L.; Arndt, M.; Gooßen, K.; Heydt, H.; Gooßen, L. J. Chem. Rev. 2015, 115, 2596.

(66) Munro-Leighton, C.; Delp, S. A.; Alsop, N. M.; Blue, E. D.; Gunnoe, T. B. Chem. Commun. 2008, 111.

(67) Beller, M.; Breindl, C.; Riermeier, T. H.; Tillack, A. J. Org. Chem. 2001, 66, 1403.

(68) Kumar, K.; Michalik, D.; Castro, I. G.; Tillack, A.; Zapf, A.; Arlt, M.; Heinrich, T.; Böttcher, H.; Beller, M. Chem. Eur. J. 2004, 10, 746.

(69) Beller, M.; Breindl, C.; Riermeier, T. H.; Eichberger, M.; Trauthwein, H. Angew. Chem. Int. Ed. 1998, 37, 3389.

(70) Seijas, J. A.; Vázquez-Tato, M. P.; Martínez, M. M. Synlett 2001, 875.
(71) Schlott, R. J.; Falk, J. C.; Narducy, K. W. J. Org. Chem. 1972, 37, 4243.

(72) Seijas, J. A.; Vázquez-Tato, M. P.; Entenza, C.; Martínez, M. M.; Ónega, M. G.; Veiga, S. Tetrahedron Lett. 1998, 39, 5073.

(73) Jaspers, D.; Doye, S. Synlett 2011, 1444.

(74) Tzalis, D.; Koradin, C.; Knochel, P. Tetrahedron Lett. 1999, 40, 6193.

(75) Ivachtchenko, A. V.; Frolov, E. B.; Mitkin, O. D.; Kysil, V. M.; Khvat, A. V.; Okun, I. M.; Tkachenko, S. E. Bioorg. Med. Chem. Lett. 2009, 19, 3183.

(76) Severin, R.; Doye, S. Chem. Soc. Rev. 2007, 36, 1407.

(77) Lui, E. K. J.; Schafer, L. L. Adv. Synth. Catal. 2016, 358, 713.

(78) Heutling, A.; Pohlki, F.; Bytschkov, I.; Doye, S. Angew. Chem. Int. Ed. 2005, 44, 2951.

(79) Katritzky, A. R.; Strah, S.; Belyakov, S. A. Tetrahedron 1998, 54, 7167.

(80) Katritzky, A. R.; Shobana, N.; Harris, P. A. Tetrahedron Lett. 1991, $32,4247$.

(81) Werner, V.; Ellwart, M.; Wagner, A. J.; Knochel, P. Org. Lett. 2015, 17, 2026.

(82) Katritzky, A. R.; Sączewski, F.; Marson, C. M. J. Org. Chem. 1985, $50,1351$. 